\title{
REMOVAL OF IRON AND ORGANIC SUBSTANCES FROM GROUNDWATER IN AN ALKALINE MEDIUM
}

\author{
Izabela KRUPIŃSKA* \\ Faculty of Civil Engineering, Architecture and Environmental Engineering, University of Zielona Góra, \\ Institute of Environmental Engineering, 15 Prof. Z. Szafrana St, 65-516 Zielona Góra, Poland
}

Received 23 November 2018; accepted 29 November 2018

\begin{abstract}
The article discusses the effectiveness of alkalinisation with calcium hydroxide or sodium hydroxide in the treatment of groundwater from Quaternary formations with an increased content of total iron (up to $6.82 \mathrm{mgFe} / \mathrm{dm}^{3}$ ) and organic substances (TOC up to $5.60 \mathrm{mgC} / \mathrm{dm}^{3}$ ). The aim of the research was to determine the effectiveness of the groundwater treatment, in particular, the removal of iron and organic substances in the sorption process and co-precipitation with calcium carbonate and magnesium hydroxide. The correction of the reaction was carried out with aqueous solutions of calcium hydroxide and sodium hydroxide in the $\mathrm{pH}$ range from 8.5 to 10.5 . As the $\mathrm{pH}$ of the water increased, the efficiency of its treatment increased. The treatment results depended on the type of alkalizing reagent, especially in the case of removal of organic substances, reduction of colour and organic substances fixed in iron-organic complexes. Higher suitability of calcium hydroxide than sodium hydroxide in alkalinisation has been demonstrated. Calcium ions introduced into the treated water together with calcium hydroxide probably neutralized organic anions fixed in iron-organic complexes and determining colour and TOC, increasing their susceptibility to adsorption.
\end{abstract}

Keywords: groundwater, organic substances, iron, alkalinisation, calcium hydroxide, sodium hydroxide, sorption, co-precipitation.

\section{Introduction}

Treating groundwater usually involves the need to remove excessive amounts of various forms of iron, manganese, organic substances and aggressive carbon dioxide. The presence of organic substances in water taken for communal purposes, including mainly humic substances, is a major problem in many groundwater treatment stations. These high-molecular organic compounds, characteristic of boggy waters and deeply deposited waters from the Miocene lignite formation, can occur in all aquifers as a result of a hydrogeological bond between them and their improper exploitation. In underground waters characterized by an increased content of organic substances, iron compounds and increased turbidity and intensity of colour, iron compounds with organic substances, most often with humic substances, are formed (Khatri, Tyagi, \& Rawtani, 2017; Knocke, Conley, \& Van Benschoten, 1992). The use of a conventional groundwater treatment system in this case does not provide the required cleaning efficiency (Albrektiene, Rimeika, \& Lubyte, 2011; Albrektiene, Rimeika, Zalieckiene, Saulys, \& Zagorskis, 2012; Marsidi,
Hasan, \& Abdullah, 2018). Well sedimenting iron(III) hydroxide agglomerates do not precipitate in the water aeration process, however, colloidal and water-soluble coloured organic iron compounds are formed, and the stability of these connections increases with the increasing concentration of organic ligands (Albrektiene, Rimeika, \& Grazeniene, 2014; Albrektiene \& Rimeika, 2017; Krupińska, Kowalczyk, \& Szczepaniak, 2013; Krupińska, 2017a, 2017b). According to numerous researchers (A. Pandey, S. Pandey, \& Mistra, 2000; Sharma, 2001), the binding ability of the humic acids is bigger in relation to $\mathrm{Fe}^{2+}$ ions whereas Schnitzer and Skinner (Schnitzer \& Skinner, 1996) state that $\mathrm{Fe}^{3+}$ ions are bound more strongly than $\mathrm{Fe}^{2+}$. Several researchers suggest various mechanisms of binding iron by the humic acids. As Gonczarow et al. (Gonczarow, Kołosow, \& Kapli, 2003) as well as Pandey et al. (2000) point out formation of chelate complexes with the humic acids in natural waters occurs as a result of an exchange reaction between hydrogen ions of carboxyl and phenol groups of the humic acids and iron cations existing under such conditions mainly in a form of hydroxo-complexes $[\mathrm{Fe}(\mathrm{OH})]^{2+},\left[\mathrm{Fe}(\mathrm{OH})_{2}\right]^{+}$, such chelate iron

*Corresponding author. E-mail: i.krupinska@iis.uz.zgora.pl 
complexes are regarded as the most stable. According to numerous researchers (Gonczarow et al., 2003; Sharma, 2001; Shiyan, Tropina, Machekhina, \& Gryaznova, 2014; Khatri et al., 2017; Krupińska, 2017a), one of the reasons for iron stabilisation by organic substances in groundwater may also be formation of the so called protective colloids of hydrophilic character as a result of adsorption of organic substances on iron(III) hydroxide surface. Summing up, the conclusion may be clear that presence of organic substances, and especially humic substances in groundwater significantly impedes removal of iron. Various attempts are being made to intensify the removal of iron occurring in combinations with organic ligands. One of the recommended methods is to use coagulation with aluminium salts or lime (Eikerokk, 2000; Liao \& Randtke, 1985, 1986; Lin, Couperthwaite, \& Millar, 2017; Marsidi et al., 2018; Nowacka, Włodarczyk-Makuła, \& Macherzyński, 2014; Nowacka \& Włodarczyk-Makuła, 2014; Urbanowska \& Kabsch-Korbutowicz, 2016). Before coagulation, oxidation of $\mathrm{Fe}^{2+}$ ions occurring in inorganic combinations is required, after which the sedimentation process is not required. The use of iron coagulant may result in the formation of coloured, difficult-to-remove combinations of $\mathrm{Fe}^{3+}$ ions with organic substances, especially humic acids (Duan \& Gregory, 2003; Huang \& Shiu, 1996; Krupińska, 2012, 2016; Myszograj, Płuciennik-Koropczuk, Jakubaszek, \& Świętek, 2017; Płuciennik-Koropczuk et al., 2017; Xu et al., 2016). During coagulation, on the one hand, the possibility of neutralizing negatively charged combinations of iron with organic compounds by coagulation cations or their positively charged hydroxide complexes is used, on the other hand, the high adsorptive capacity of precipitated aluminium hydroxide or iron is also used (Cheng \& Ghi, 2002; Davis \& Edwards, 2014; Ghernaout, 2014; Ghernaout \& Boucherit, 2015; Lin, Couperthwaite, Huang, Dempsey, \& Hu, 2014; Nowacka \& WłodarczykMakuła, 2014; Saxena, Brighu, \& Choudhary, 2018; Sillanpää, Ncibi, Matilainen, \& Vepsäläinen, 2018; Wolska, 2011; Xu et al., 2018). During coagulation carried out in an alkaline medium, the degree of the removal of iron compounds as well as organic pollutants and their combinations with iron depends on the processes of adsorption and co-precipitation with calcium carbonate and magnesium hydroxide, as well as neutralization of iron and organic combinations with a negative charge by calcium cations (Ghernaout et al., 2018; Świderska-Bróż, 1987; Wang, Wu, Shammas, \& Vaccari, 2005). Due to the fact that during the coagulation with lime the destabilization of colloids has a smaller share in the total degree of removal of pollutants, it is not a typical coagulation. At $\mathrm{pH}=$ ca.9.3-9.5, the maximum precipitation of $\mathrm{CaCO}_{3}$ takes place, and at $\mathrm{pH} \geq 10.2$ precipitation of $\mathrm{Mg}(\mathrm{OH})_{2}$, which is a good adsorbent, and because of the positive electric charge it effectively binds organic anions (Brastad \& He, 2013; Esmaeilirad, Carlson, \& Ozbek, 2015; Mahasti, Shih, Vu, \& Huang, 2017; Randtke, Thiel, Marcia, Liao, \& Yamaya, 1982; Rescorla, Semmens, \& Hozalski, 2017; Wang et al., 2005; Zotter \& Licsko, 1992). For this reason, coagulation in the alkaline environment is often referred to as coagulation-adsorption. Freshly precipitated calcium carbonate has a specific surface area of a dozen or so $\mathrm{m}^{2} / \mathrm{g}$, which decreases with the age of the sediment. Calcium carbonate has a crystalline structure, a negative electric charge and begins to precipitate from the solution at $\mathrm{pH}$ ca.9.3, while magnesium hydroxide precipitates at $\mathrm{pH}=10.2 . \mathrm{pH}=11.2-11.5$ is required to completely precipitate magnesium hydroxide. Magnesium hydroxide does not have crystalline structure and its particles are positively charged (Liao \& Randtke, 1985; Moel, Verberk, \& Van Dijk, 2007; Świderska-Bróż, 1987; Wolska, 2015). The $\mathrm{pH}$ required for the precipitation of calcium carbonate and magnesium hydroxide can be reduced by increasing the concentration of $\mathrm{Mg}^{2+}$ ions in the solution. The precipitating calcium carbonate, as well as partially magnesium hydroxide, very effectively sorb pollutants by embedding them in their volume. Significant amounts of admixtures are also sorbed on the surface of precipitated sorbents, mainly magnesium hydroxide as a result of physical and chemical sorption. The sorbate binding force depends on its type, and its sorption changes the rate of volume growth and the shape of the precipitated particles of calcium carbonate and magnesium hydroxide. Among the organic pollutants, compounds containing oxygen functional groups, e.g., $-\mathrm{COOH}$ and $-\mathrm{OH}$ are very efficiently sorbed, which confirms the high efficiency of the removal of humic substances obtained during lime coagulation. The susceptibility of organic pollutants to sorption increases with their molecular weight, and decreases with increasing solubility. It was shown that, along with the increase in the solubility of the fulvic acid fraction, the effectiveness of their sorption on $\mathrm{CaCO}_{3}$ molecules decreased from 31 to $13 \%$ (Świderska-Bróż, 1987). Due to the importance of solubility, electrically neutral (sparingly soluble) metal hydroxides are well sorbed. Since both $\mathrm{CaCO}_{3}$ crystals as well as the majority of organic admixtures and other colloids present in the water have a negative electric charge, the presence of $\mathrm{Ca}^{2+}$ ions or other multivalent cations is necessary for the proper course of sorption in the solution being purified (Gao, Yan, \& Korshin, 2015; Zhou, Yan, Liu, Wang, \& Qu, 2017). They fulfil the role of factors that neutralize organic anions and bridge emerging agglomerates. In the presence of $\mathrm{Mg}(\mathrm{OH})_{2}$, a sorbent with a positive electric charge, the presence of cations also increases the efficiency of anion sorption, but is not so important. Interaction between $\mathrm{CaCO}_{3}$ and $\mathrm{Mg}(\mathrm{OH})_{2}$ is also possible, which results in the formation of flocs with an electric charge depending on the quantity of reacting compounds and the presence of other cations and anions in water. The disadvantage of lime coagulation is the elimination of magnesium from water and the need to restore the carbonate-calcium balance in water after coagulation. It can be obtained using a recarbonisation process, i.e. saturating water with carbon dioxide (Ghernaout et al., 2018; Ayoub, Zayyat, \& Al-Hindi, 2014a; Ayoub, BinAhmed, Al-Hindi, \& Azizi, 2014b; Chen, Fan, An, Cheng, \& Tan, 2016; Dowling, O’ Dwyer, 
\& Adley, 2015; Liao \& Randtke, 1986; Randtke et al., 1982; Yan, Lu, Gao, Benedetti, \& Korshin, 2015). In water treatment for purposes of human consumption, lime is rarely used as a basic coagulant, more often it can be used to correct the alkalinity of water before coagulation, to bind aggressive carbon dioxide after coagulation or as a substance supporting the coagulation with iron salts, due to the $\mathrm{pH}$ value of their effective operation. The optimum $\mathrm{pH}$ of coagulation with aluminium salts is 5-6, while for iron salts it is 5-6 and above 9 (Krupińska, 2012, 2016; Wolska, 2013). According to many authors, the coagulation process carried out in an alkaline environment can be used to purify waters in which there is a significant amount of organic matter, because in this process not only suspended and colloidal contaminants are removed, but also dissolved organic substances. High degree of organic pollutants removal is ensured by alkalinisation of water up to $\mathrm{pH}>10$, where there are conditions of sorption and coprecipitation of organic pollutants with calcium carbonate and magnesium hydroxide precipitating from water (Liao \& Randtke, 1986; Randtke et al., 1982; Wang et al., 2005). The article presents and discusses the results of research on the removal of pollutants from groundwater, in particular the removal of iron and organic substances, in the sorption process and co-precipitation with calcium carbonate and magnesium hydroxide.

\section{Materials and methods}

The subject of the study was groundwater from Quaternary formations. The groundwater intake is located in the area of the Warsaw-Berlin Urstromtal, 3-4 km from the shoreline of the river, in the area of the Odra river oxbow. They are 22 wells, 19 to 30 meters deep, located near peat bogs. The ranges of values of selected indicators of the physical-chemical composition of raw water and water after aeration and 2-hour sedimentation are presented in Table 1. Aerating the water has ensured high efficiency of ca. 95\% Fe(II) oxidation to Fe(III), increase in colour and turbidity. The Fe(III) compounds formed were characterized by a very high degree of dispersion, and thus, poor sedimentation properties. Aeration and $2 \mathrm{~h}$ sedimentation made it possible to reduce the total iron concentration by ca. $11 \%$, organic substances by only $1 \%$ and, unfortunately, increased turbidity and colour intensity (Table 1). Presence of significant concentrations of $\mathrm{Fe}$ (III) iron to $5.74 \mathrm{mgFe} / \mathrm{dm}^{3}$ in purified water, and at the same time high colour up to $60 \mathrm{mgPt} / \mathrm{dm}^{3}$ and almost no removal of organic contaminants (only $1 \%$ TOC) suggest that part of the organic pollutants present in water formed with iron combinations dispersed to a large extent.

This was confirmed by the results of the groundwater filtration tests (after 15-minute aeration and $2 \mathrm{~h}$ sedimentation) through filters with different pore diameters (filter: soft, hard or with $0.45 \mu \mathrm{m}$ pore diameter) or through an "incorporated" sand filter bed covered with iron and manganese oxides at a speed of $5 \mathrm{~m} / \mathrm{h}$ (Table 2).
The required efficiency of iron compounds removal $\left(\leq 0.2 \mathrm{mgFe} / \mathrm{dm}^{3}\right)$ and decreasing turbidity ( $\left.\leq 1 \mathrm{NTU}\right)$, which were $0.12 \mathrm{mgFe} / \mathrm{dm}^{3}$ and 0.07 NTU respectively, was ensured only by filtration through the filter with $0.45 \mu \mathrm{m}$ pore diameter. Comparison of the amounts of pollutants removed as a result of filtration through the "incorporated" sand bed $\left(V_{f}=5 \mathrm{~m} / \mathrm{h}\right)$ and through a soft filter showed that the effects of removing iron compounds were comparable. However, in the case of elimination of

Table 1. Characteristics of groundwater quality before and after $\mathrm{Fe}(\mathrm{II})$ oxidation and sedimentation

\begin{tabular}{|l|c|c|c|}
\hline \multicolumn{1}{|c|}{ Indicator } & Unit & Raw water & $\begin{array}{c}\text { Water after Fe(II) } \\
\text { oxidation and } \\
\text { sedimentation }\end{array}$ \\
\hline Temperature & ${ }^{\circ} \mathrm{C}$ & $9.2-12.1$ & $10.8-18.4$ \\
\hline $\mathrm{pH}$ & - & $6.88-7.11$ & $7.61-7.99$ \\
\hline $\begin{array}{l}\text { Dissolved } \\
\text { oxygen }\end{array}$ & $\mathrm{mgO}_{2} / \mathrm{dm}^{3}$ & $0.54-1.22$ & $9.94-11.37$ \\
\hline Colour & $\mathrm{mgPt} / \mathrm{dm}^{3}$ & $21-30$ & $29-60$ \\
\hline Turbidity & $\mathrm{NTU}$ & $15-25$ & $32-35$ \\
\hline Iron total & $\mathrm{mgFe} / \mathrm{dm}^{3}$ & $5.30-6.82$ & $4.71-6.07$ \\
\hline Iron $(\mathrm{II})$ & $\mathrm{mgFe} / \mathrm{dm}^{3}$ & $3.09-4.26$ & $0.22-0.33$ \\
\hline Iron $(\mathrm{III})$ & $\mathrm{mgFe} / \mathrm{dm}^{3}$ & $1.04-3.55$ & $4.49-5.74$ \\
\hline $\begin{array}{l}\text { Iron fixed in } \\
\text { metal-organic } \\
\text { complexes }\end{array}$ & $\mathrm{mg} / \mathrm{dm}^{3}$ & $1.54-1.70$ & $1.80-2.00$ \\
\hline Calcium & $\mathrm{mgCa} / \mathrm{dm}^{3}$ & $97-122$ & $97-122$ \\
\hline Magnesium & $\mathrm{mgMg} / \mathrm{dm}^{3}$ & $11-20$ & $11-20$ \\
\hline Alkalinity & $\mathrm{mval} / \mathrm{dm}^{3}$ & 3.60 & 3.60 \\
\hline Manganese & $\mathrm{mgMn} / \mathrm{dm}^{3}$ & 0.34 & 0.34 \\
\hline TOC & $\mathrm{mgC} / \mathrm{dm}^{3}$ & $3.98-5.60$ & $3.98-5.55$ \\
\hline DOC & $\mathrm{mgC} / \mathrm{dm}^{3}$ & $3.00-4.30$ & $3.00-4.30$ \\
\hline
\end{tabular}

Table 2. Influence of filtration on the effectiveness of removing pollutants from groundwater after aeration and 2-hour sedimentation

\begin{tabular}{|c|c|c|c|c|c|}
\hline \multirow[b]{2}{*}{$\begin{array}{c}\text { Indicator, } \\
\text { Unit }\end{array}$} & \multirow[b]{2}{*}{$\begin{array}{l}\text { Raw } \\
\text { water }\end{array}$} & \multicolumn{4}{|c|}{$\begin{array}{c}\text { Water after aeration, sedimentation and } \\
\text { filtration by: }\end{array}$} \\
\hline & & 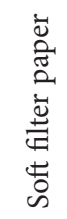 & 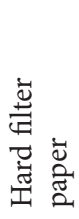 & 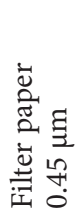 & 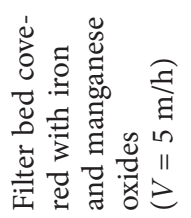 \\
\hline $\begin{array}{l}\text { Colour, } \\
\mathrm{mgPt} / \mathrm{dm}^{3}\end{array}$ & 27 & 37 & 15 & 5 & 36 \\
\hline $\begin{array}{l}\text { Turbidity, } \\
\text { NTU }\end{array}$ & 19 & 10 & 4 & 0.07 & 13 \\
\hline $\begin{array}{l}\text { Iron total, } \\
\mathrm{mgFe} / \mathrm{dm}^{3}\end{array}$ & 5.83 & 1.65 & 0.60 & 0.12 & 1.60 \\
\hline $\begin{array}{l}\text { Iron (III), } \\
\mathrm{mgFe} / \mathrm{dm}^{3}\end{array}$ & 2.38 & 1.50 & 0.50 & 0.06 & 1.40 \\
\hline $\begin{array}{l}\text { Iron (II), } \\
\mathrm{mgFe} / \mathrm{dm}^{3}\end{array}$ & 3.45 & 0.15 & 0.10 & 0.06 & 0.15 \\
\hline $\begin{array}{l}\text { TOC, } \\
\mathrm{mgC} / \mathrm{dm}^{3}\end{array}$ & 4.30 & 4.26 & 4.00 & 3.05 & 3.70 \\
\hline
\end{tabular}


organic compounds, better results were obtained as a result of filtration through the "incorporated" sand bed (Table 2). The results of the tests presented in Table 2 also showed that the dominant amount of organic pollutants (ca. 71\%) remaining in the filtrate were dissolved fractions, and the iron compounds (mainly Fe(III)) in the aerated water occurred in the form of colloids and very hard sedimenting particles.

Therefore, in order to intensify the treatment of groundwater, the alkalinisation process was included in the technological system. The aim of the research was to determine the effectiveness of the groundwater treatment, in particular, the removal of iron and organic substances in the sorption process and co-precipitation with calcium carbonate and magnesium hydroxide. Prior to the alkalinisation process, in order to ensure the oxidation of $\mathrm{Fe}^{2+}$ to $\mathrm{Fe}^{3+}$ groundwater was aerated for 15 minutes. The correction of the reaction was carried out with aqueous solutions of calcium hydroxide and sodium hydroxide in the $\mathrm{pH}$ range from 8.5 to 10.5 . The flocculation time was 25 minutes with the rotational speed of the stirrers $30 \mathrm{rpm}$, and the sedimentation time was two hours. After the sedimentation process, the water samples underwent filtration through a soft filter or filtration at a speed of $5 \mathrm{~m} / \mathrm{h}$ through the sand "incorporated" filter bed covered with iron and manganese oxides (bed height $1 \mathrm{~m}$ and $d_{10}=$ $0.85 \mathrm{~mm}, d_{60}=1.3 \mathrm{~mm}$ ). The studies also determined the effect of the flocculation time, varying from 15 to 60 minutes, on the efficiency of removing pollutants from groundwater during alkalinisation with calcium hydroxide up to $\mathrm{pH}=10$. The physical-chemical composition of both the raw as well as treated water was determined according to the International Standard methods. A decrease in the values of the studied water quality indicators in relation to the values permissible in the water for human consumption was assumed as the required effectiveness of water treatment (Regulation of the Minister of Health dated December 7,2017$)$. The NOM concentration was monitored by measuring the TOC and DOC. The TOC and DOC were measured using the thermal method and a Shimadzu TOC analyzer. DOC was analyzed by the TOC analyzer after filtration through $0.45 \mu \mathrm{m}$ pore diameter membranes.

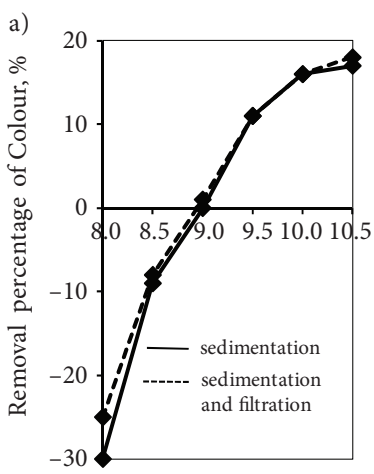

$\mathrm{pH}$

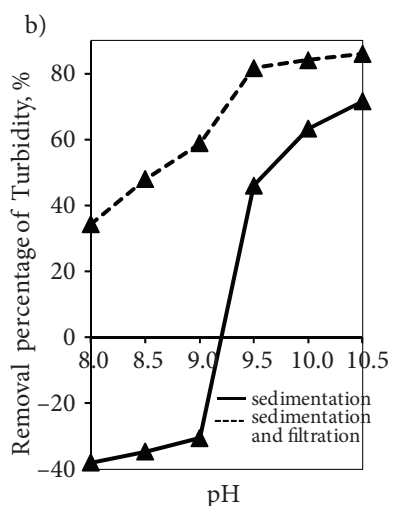

$\mathrm{pH}$
Figure 1. Influence of $\mathrm{pH}$ on the efficiency of reduction of colour (a) and turbidity (b) in the process of $\mathrm{Ca}(\mathrm{OH})_{2}$ alkalinisation and two-hour sedimentation
The colour (according to Pt scale), total iron, iron (II) concentrations were determined with the Agilent Cary 60 UV-VIS spectrophotometer. Iron (II) was measured using the 1.10 phenanthroline method. Total iron was measured using the same method. As a reducing agent of ferric ions to ferrous ions, hydroxylamine hydrochloride was used. Iron fixed with organic substances was determined as a difference between the iron concentration determined in the post-mineralization test and without mineralization, taking into account the amount of iron-inorganic bounds. The water samples were mineralized under reflux with nitric acid (V) and hydrochloric acid for 30 minutes, then sulfuric acid (VI) was dosed and the solution was evaporated until appearance of white fumes. Manganese, calcium and magnesium concentrations was determined with the atomic emission spectroscopy (ISP-OES, 5300DV, Perkin Elmer Company, US). The temperature and $\mathrm{pH}$ of the raw water and the purified water was determined with an WTW Multi Line P4 with a combination pH electrode with temperature corrections. The dissolved oxygen of the raw water and the purified water was determined with an WTW Multi 3410 SET 4 with an optical oxygen sensor $\mathrm{FDO}^{\mathrm{R}} 925$ (Germany). Turbidity was measured using the Hach $2100 \mathrm{~N}$ Turbidimeter. The alkalinity was determined with a titrimetric method against methyl orange using $0.1 \mathrm{M}$ aqueous solutions of $\mathrm{HCl}$.

\section{Results and discussion}

The tests determined effectiveness of removing pollutants from groundwater after aeration in the alkalinisation process with calcium hydroxide or sodium hydroxide in the $\mathrm{pH}$ range from 8.5 to 10.5 .

\subsection{Alkalinisation with calcium hydroxide}

The effects of tests presented in Figure 1 and Figure 2 indicate that the effectiveness of water treatment as a result of alkalinisation with calcium hydroxide increased with increasing concentration of $\mathrm{OH}^{-}$ions. The maximum reduction in the concentration of total iron, TOC, DOC, colour intensity and turbidity was obtained at $\mathrm{pH}=$ 10.5 (Figure 1 and Figure 2), in which, in addition to
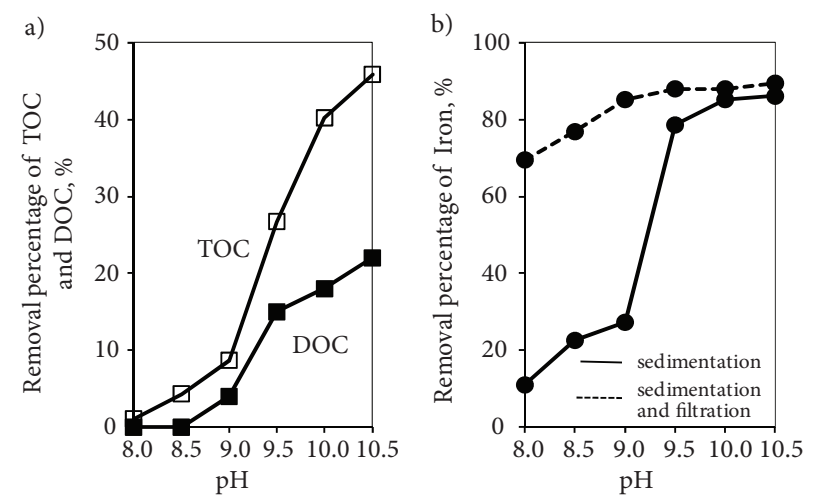

Figure 2. Influence of $\mathrm{pH}$ on the efficiency of reduction of TOC, DOC (a) and total iron (b) in the process of $\mathrm{Ca}(\mathrm{OH})_{2}$ alkalinisation and two-hour sedimentation 
the precipitation of calcium carbonate, the precipitation of magnesium hydroxide with good adsorption properties also begins. Thus, the degree of water purification depended on both the processes of adsorption and coprecipitation of pollutants with $\mathrm{CaCO}_{3}$ and $\mathrm{Mg}(\mathrm{OH})_{2}$ precipitating from water. However, the total iron concentration $\left(\leq 0.2 \mathrm{mg} / \mathrm{dm}^{3}\right)$, colour intensity $\left(\leq 15 \mathrm{mgPt} / \mathrm{dm}^{3}\right)$ and turbidity $(\leq 1 \mathrm{NTU})$ required for water intended for human consumption were not obtained. The smallest concentrations of total iron, colour and turbidity in water after alkalinisation to $\mathrm{pH}=10.5$ and sedimentation were: $0.95 \mathrm{mgFe} / \mathrm{dm}^{3}, 13 \mathrm{mg} \mathrm{Pt} / \mathrm{dm}^{3}$ and $7.04 \mathrm{NTU}$ respectively. In the opinion of Ghernaout, Świderska-Bróż and Wang et al. (Ghernaout et al., 2018; Świderska-Bróż, 1987; Wang et al., 2005) removal of organic substances increase with increasing $\mathrm{pH}$, since they will dissociate to a greater extent and bind $\mathrm{Ca}^{2+}$ more strongly.

According to Liao and Randtke (Liao \& Randtke, 1985) and Zhou et al. (2017) one of the best ways to improve removal of many contaminants especially organic contaminants is precipitate a significant amount of $\mathrm{Mg}(\mathrm{OH})_{2}$ by adding enough lime to raise the $\mathrm{pH}$ to about 10.5-11.0 and adding magnesium salts if they are not already present in the raw water. The types of contaminants that are expected to adsorb onto and coprecipitate with $\mathrm{Mg}(\mathrm{OH})_{2}$ are generally the same as those that adsorb onto $\mathrm{CaCO}_{3}$, however removal of anionic species will be enhanced by the reinforcement of chemical forces by electrostatic forces and by the superior sorptive properties of the $\mathrm{Mg}(\mathrm{OH})_{2}$. Removal of cationic species by $\mathrm{Mg}(\mathrm{OH})_{2}$ will be inhibited by electrostatic repulsion. Moel et al. (2007), ŚwiderskaBróż (1987) and Teh Fu Yen (2007) found $\mathrm{Mg}(\mathrm{OH})_{2}$ present as blossom-petal-like crystals in softening sludge it is possible that $\mathrm{Mg}(\mathrm{OH})_{2}$ is initially precipitated in the form of gelantinous colloids that function as powerful adsorbents able to effectively remove contaminants. According Zotter and Licsko (1992) in alkaline media the magnesium hydroxide is almost comparable in effectiveness to the aluminium or iron(III) hydroxide coagulants in neutral media. The application of filtration of water samples through a soft filter improved the effects of removing total iron, especially in the $\mathrm{pH}$ range up to 9.5 , as well as reducing turbidity (Figure $1 \mathrm{~b}$ and Figure $2 \mathrm{~b}$ ). The influence of filtration found and the changes in the amount of pollutants removed in the $\mathrm{pH}$ function testify to the positive role of the precipitating $\mathrm{CaCO}_{3}$ as a sorbent and a factor co-precipitating pollutants removed from water (Figure 1 and Figure 2). To adsorb onto on ionic solid like $\mathrm{CaCO}_{3}$, a compound needs to be moderately hydrophilic. Compounds that are too hydrophilic will remain in the aqueous phase, but highly hydrophobic compounds cannot adsorb onto $\mathrm{CaCO}_{3}$ because they possess neither the electrical charge nor the calcium complexing functional groups necessary to effect adsorption (Liao \& Randtke, 1986). In the corrected range of water $\mathrm{pH}$, even as a result of the use of filtration, the required effectiveness of removing iron compounds and decreasing turbidity has not been obtained. The lowest concentration of total iron and turbidity were $0.72 \mathrm{mgFe} / \mathrm{dm}^{3}$ and 3.49 NTU respectively after alkalinizing the water to $\mathrm{pH}=10.5$ and two hours of sedimentation. A sufficient reduction in colour intensity has already been provided by alkalinisation with calcium hydroxide to $\mathrm{pH}=10$. The colour intensity in water after alkalinisation to $\mathrm{pH}=10$ and two-hour sedimentation was $14 \mathrm{mgPt} / \mathrm{dm}^{3}$. The complete removal of manganese compounds from water was obtained by alkalinisation with calcium hydroxide, dosed in an amount that ensures $\mathrm{pH} \geq 10$, sedimentation and filtration through a soft filter. According to Teh Fu Yen (2007) and Moel et al. (2007), the normal oxidation-reduction potential $\left(\mathrm{E}_{0}\right)$ of $\mathrm{Mn}^{2+} / \mathrm{Mn}^{4+}$ system decreases with increasing the $\mathrm{pH}$ of the water, its value at $\mathrm{pH}=7$ is ca. $0.5 \mathrm{~V}$ and at $\mathrm{pH}$ ca.9.5 is ca. $0.25 \mathrm{~V}$. Effective oxidation of divalent manganese with oxygen at a rate that is useful for technological purposes only takes place at $\mathrm{pH} \geq 9.5$ according to reaction 1 :

$$
2 \mathrm{Mn}^{2+}+\mathrm{O}_{2}+2 \mathrm{H}_{2} \mathrm{O} \rightarrow 2 \mathrm{MnO}_{2}+4 \mathrm{H}^{+} \text {. }
$$

The required alkaline reaction of $\mathrm{Mn}^{2+}$ oxidation with oxygen dissolved in water explains the insufficient effects of demanganizing water at $\mathrm{pH}<9.5$ obtained during alkalinisation with calcium hydroxide (Figure 3 ).

The analysis of the obtained test results showed also that the effectiveness of removing organic pollutants as a result of alkalinisation with calcium hydroxide increased with the amount of removed total iron (Figure 4), which suggests the joint removal of these pollutants.

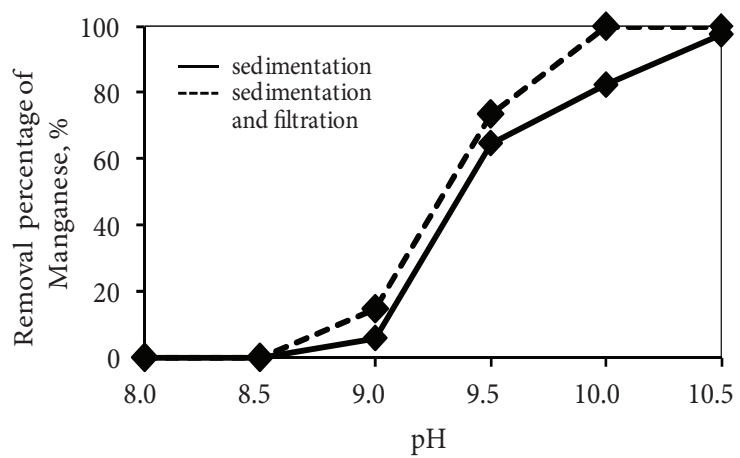

Figure 3. Influence of $\mathrm{pH}$ on the efficiency of reduction of manganese in the process of $\mathrm{Ca}(\mathrm{OH})_{2}$ alkalinisation and two-hour sedimentation

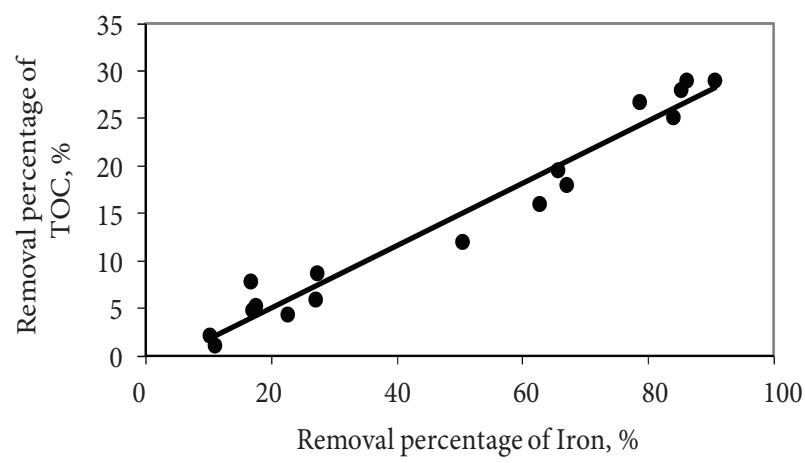

Figure 4. Dependence of the TOC reduction effectiveness on the effectiveness of removing total iron in water samples after the $\mathrm{Ca}(\mathrm{OH})_{2}$ alkalinisation in the range of $\mathrm{pH}=8.5 \div 10.5$ and two-hour sedimentation 
Increasing the concentration of $\mathrm{OH}^{-}$ions $(\mathrm{pH} \geq 9.0)$ shortened the $\mathrm{Fe}(\mathrm{II})$ oxidation time, as evidenced by the lack of turbidity and colour of the samples of water after sedimentation found for the majority of samples treated at natural $\mathrm{pH}$ (Table 1 and Figure 1). Despite the formation of iron (III) combinations that sediment better as a result of alkalinisation with calcium hydroxide, in order to remove them from the water the filtration was necessary whose role in reducing turbidity and total iron concentration was lower in the $\mathrm{pH}$ range from 9.5 to 10.5 than in the case of treating water with an uncorrected $\mathrm{pH}$ value (Table 3).

Table 3. Effect of alkalinisation with calcium hydroxide in the range of $\mathrm{pH}=8.5 \div 10.5$ on the filtration efficiency $\left(\Delta \eta_{\mathrm{f}}, \%\right)$ in reducing the concentration of total iron and turbidity

\begin{tabular}{|l|c|c|c|c|c|c|}
\hline \multirow{2}{*}{$\begin{array}{c}\text { Filtration } \\
\text { efficiency, } \\
\%\end{array}$} & $\begin{array}{c}\text { 8.00 } \\
\text { (without } \\
\text { alkalisation) }\end{array}$ & 8.50 & 9.00 & 9.50 & 10.00 & 10.50 \\
\hline $\begin{array}{l}\Delta \eta_{\mathrm{f}} \text { Total } \\
\text { Iron }\end{array}$ & 58.50 & 54.25 & 57.90 & 9.00 & 2.80 & 1.40 \\
\hline $\begin{array}{l}\Delta \eta_{\mathrm{f}} \\
\text { Turbidity }\end{array}$ & 73.00 & 83.00 & 90.00 & 36.00 & 21.00 & 14.00 \\
\hline
\end{tabular}

a)

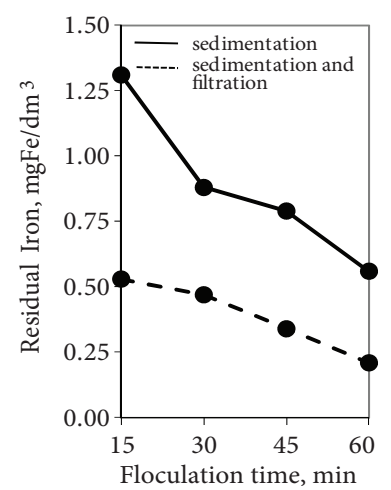

b)

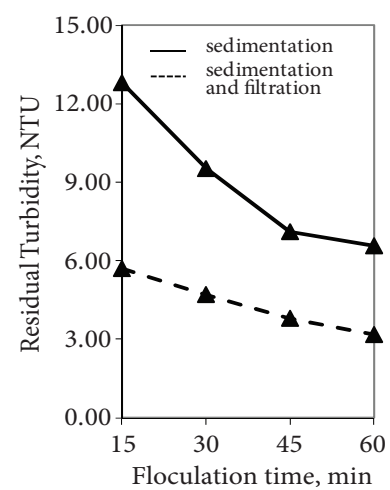

Figure 5. Influence of flocculation time on residual iron (a) and residual turbidity $(\mathrm{b})$ in the water after the $\mathrm{Ca}(\mathrm{OH})_{2}$ alkalinisation to $\mathrm{pH}=10$ a)

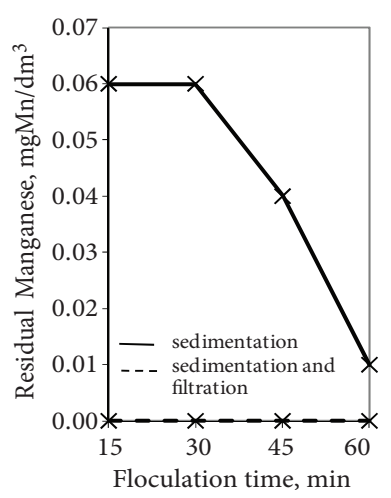

b)

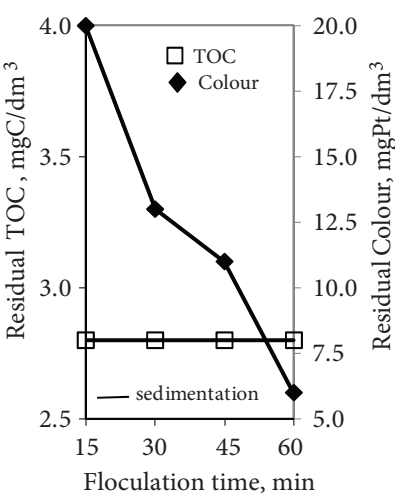

Figure 6. Influence of flocculation time on residual manganese (a) and residual TOC and residual colour (b) in the water after the $\mathrm{Ca}(\mathrm{OH})_{2}$ alkalinisation to $\mathrm{pH}=10$
The analysis of the dependences presented in Figure 5 and 6 showed that after water alkalinisation with calcium hydroxide to $\mathrm{pH} 10$ with increasing flocculation time from 15 to $60 \mathrm{~min}$ (which was supposed to improve the sedimentation properties of the precipitated agglomerates after alkalinisation with calcium hydroxide), the level of contamination of water samples decreased, with the exception of removing organic substances. The effectiveness of removing organic substances did not depend on the time of flocculation changed in the range of 15-60 min and amounted to $33 \%$. Filtration through a soft filter provided further removal of iron compounds and decreased turbidity (Figure 5). According to Kowal and ŚwiderskaBróż (2007) the reaction of the purified water was a more important parameter in removing organic substances than flocculation time.

However, the use of the longest flocculation time of 60 minutes and the filtration of water samples through a soft filter did not provide the required values of the total iron concentration and turbidity, which amounted to 0.21 $\mathrm{mgFe} / \mathrm{dm}^{3}$ and $3.18 \mathrm{NTU}$ respectively. Sufficient reduction of manganese concentration in water after $2 \mathrm{~h}$ sedimentation $\left(0.04 \mathrm{mgMn} / \mathrm{dm}^{3}\right)$ was provided by $45 \mathrm{~min}$ flocculation, and the complete removal of manganese compounds from water was obtained using the shortest flocculation time of $15 \mathrm{~min}$ and additionally filtration through a soft filter.

\subsection{Alkalinisation with calcium hydroxide or sodium hydroxide}

The effects of the treatment of aerated water as a result of alkalinisation with calcium hydroxide or sodium hydroxide in the range of $\mathrm{pH}=8.50-10.50$ and two-hour sedimentation are shown in Figure 7-9. The concentration of $\mathrm{OH}^{-}$ions determined the effectiveness of removing total iron, organic substances (TOC and DOC), iron fixed in metal-organic complexes (Figure $7 \mathrm{a}$ and Figure $8 \mathrm{a}, 8 \mathrm{~b}$ and decreasing the turbidity and colour of water (Figure 7a, 7b).

The comparison of the amounts of pollutants removed from the water indicates the higher suitability of calcium
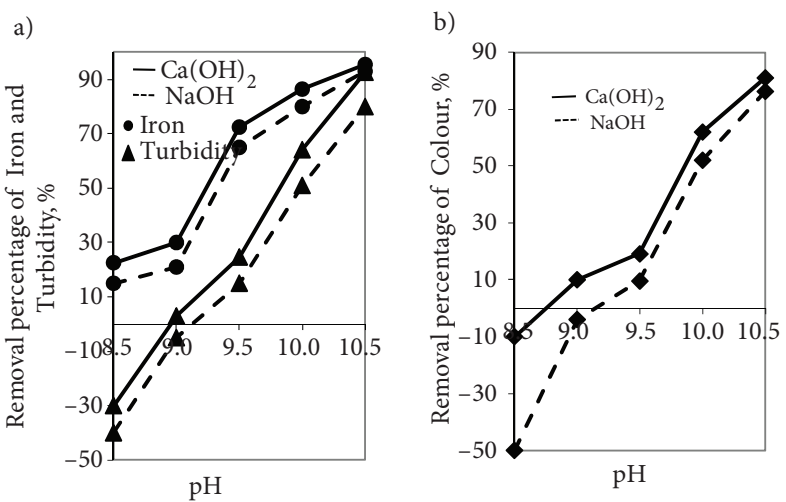

Figure 7. Effect of the type of alkalizing reagent: $\mathrm{Ca}(\mathrm{OH})_{2}$ or $\mathrm{NaOH}$ on the amount of iron and turbidity (a) and colour (b) removed from the water in the sedimentation process 

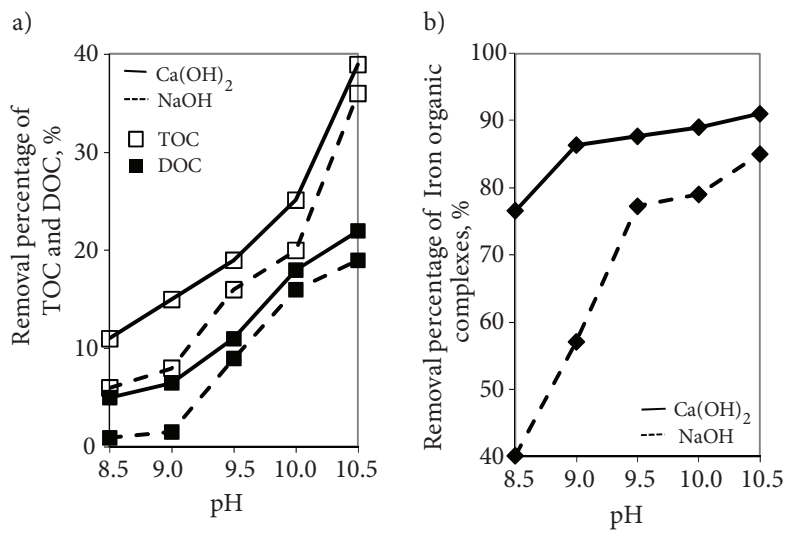

Figure 8. Effect of the type of alkalizing reagent: $\mathrm{Ca}(\mathrm{OH})_{2}$ or $\mathrm{NaOH}$ on the amount of TOC and DOC (a) and iron organic complexes (b) removed from the water in the sedimentation process

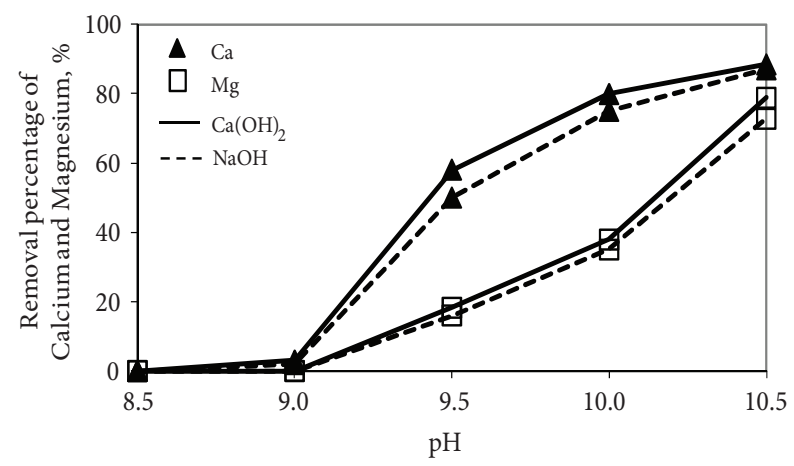

Figure 9. Effect of the type of alkalizing reagent: $\mathrm{Ca}(\mathrm{OH})_{2}$ or $\mathrm{NaOH}$ on the effectiveness of removing calcium and magnesium from the water in the sedimentation process

hydroxide for alkalinisation, especially to $\mathrm{pH}=9.5$ corresponding to the minimum solubility of calcium carbonate.

This indicates that $\mathrm{Ca}^{2+}$ cations introduced into the treated water during the alkalinisation probably neutralized organic anions influencing the colour and TOC and fixed in iron-organic complexes, increasing their susceptibility to adsorption, and also fulfilled the role of cations bridging the agglomerates formed. Most organic contaminants in water are negatively charged and can adsorb onto $\mathrm{CaCO}_{3}$ only if there are specific chemical forces strong enough to overcome electrostatic repulsion. Adsorption of anionic chemicals onto $\mathrm{CaCO}_{3}$ can be enhanced by the presence of $\mathrm{Ca}^{2+}$, as demonstrated by Liao and Randtke using groundwater fulvic acid (Liao \& Randtke, 1985). According to Świderska-Bróż (1987) and Randtke et al. (1982) decrease in the colour and removal of organic substances depended on the $\mathrm{pH}$ of the treated solutions and the presence of $\mathrm{Ca}^{2+}$ and $\mathrm{Mg}^{2+}$ ions. For solutions without these cations (model solutions prepared on the basis of distilled water), according to Świderska-Bróż (1987), in the $\mathrm{pH}$ range to 14 , practically no organic pollutants were removed. The difference in the effectiveness of the precipitating factors tested, $\mathrm{Ca}(\mathrm{OH})_{2}$ and $\mathrm{NaOH}$ decreased with increasing $\mathrm{pH}$ (Figure 7-9), and therefore, also the amount of precipitated calcium carbonate, and mainly magnesium hydroxide characterized by good sorption properties and whose particles have a positive charge. According to the literature (Brastad \& He, 2013; Ghernaout et al., 2018; Teh Fu Yen, 2007; Mahasti et al., 2017; Moel et al., 2007), calcium carbonate begins to precipitate from the solution at $\mathrm{pH}$ ca.9.3, while magnesium hydroxide precipitates at $\mathrm{pH}=10.2 \mathrm{pH}=11.2-11.5$ is required to completely precipitate magnesium hydroxide. In the tested $\mathrm{pH}$ range, no transition of $\mathrm{Fe}(\mathrm{OH})_{3}$ to soluble $\mathrm{Fe}(\mathrm{OH})_{4}^{-}$ anion was found, and the filtration through a sand bed at a filtration rate of $5 \mathrm{~m} / \mathrm{h}$ improved the effects of removing iron, organic matter, colour and turbidity. According to the literature, the solubility of $\mathrm{Fe}(\mathrm{OH})_{3}$ decreases with the increase in $\mathrm{pH}$ to ca. 8 , and then increases. A significant increase in solubility at $\mathrm{pH}>10$ results from the transition of $\mathrm{Fe}(\mathrm{OH})_{3}$ to soluble $\mathrm{Fe}(\mathrm{OH})_{4}{ }^{-}$anion. The required total iron concentration and turbidity reduction, which amounted to $0.18 \mathrm{mgFe} / \mathrm{dm}^{3}$ and $0.88 \mathrm{NTU}$ respectively, were obtained only through alkalinisation with calcium hydroxide to $\mathrm{pH}=10.5$ and additional filtration through an incorporated sand bed. Regardless of the type of alkalizing agent used: calcium hydroxide or sodium hydroxide, a disadvantage of the alkalinisation was the removal of calcium and magnesium ions from the water, as shown in Figure 9.

\section{Conclusions}

Analysis of the results showed that:

1 . With the increase of the $\mathrm{pH}$ of the water due to the alkalinisation with calcium hydroxide or sodium hydroxide, the efficiency of its treatment increased, which proves the positive role of the co-precipitation of inorganic and organic pollutants with $\mathrm{CaCO}_{3}$ molecules and, at a higher concentration of $\mathrm{OH}^{-}$ions, also with precipitating $\mathrm{Mg}(\mathrm{OH})_{2}$ and $\mathrm{MnO}_{2}$

2. The degree of removal of organic pollutants increased with the amount of removed total iron, which suggests the joint removal of these pollutants.

3. Alkalinisation of water after aeration with calcium hydroxide to $\mathrm{pH} \geq 10$ and sedimentation and filtration through a soft filter paper ensured complete elimination of manganese, sufficient colour reduction, but no required turbidity and total iron concentration in which iron (III) predominated. The required total iron concentration and turbidity reduction, were obtained only through alkalinisation with calcium hydroxide to $\mathrm{pH}=10.5$ and additional filtration through an incorporated sand bed covered with iron and manganese oxides.

4. Extending the flocculation time to $60 \mathrm{~min}$, which was supposed to improve the sedimentation properties of the precipitated agglomerates after alkalinisation with calcium hydroxide, also failed to provide acceptable turbidity and total iron concentration. The turbidity in treated water was $3.18 \mathrm{NTU}$, and the total iron concentration was $0.21 \mathrm{mgFe} / \mathrm{dm}^{3}$. 
5. The comparison of the effects of water treatment obtained after the alkalinisation process with lime and sodium hydroxide shows the importance of the precipitating $\mathrm{CaCO}_{3}$ and the presence of $\mathrm{Ca}^{2+}$ ions in neutralizing organic anions, organic anions fixed in iron-organic complexes as well as compounds that determine the colour of water.

6. The analysis of the obtained test results showed that in the case of groundwater treatment characterized by an increased content of organic substances, iron compounds and increased colour intensity, the removal of pollutants, in particular the removal of organic substances and lowering the colour intensity can be supported by the use of calcium hydroxide as alkalising agent. The disadvantage of alkalinisation is the removal from the treated water of calcium and magnesium ions, which are necessary for the proper functioning of the human body. The need to enrich water after alkalinisation with calcium and magnesium ions should then be considered.

\section{References}

Albrektiene, R., Rimeika, M., \& Lubyte, E. (2011, 19-20 May). The removal of iron-organic complexes from drinking water using coagulation process [CD]. In 8th International Conference "Environmental Engineering" (pp. 509-512). Vilnius, Lithuania.

Albrektiene, R., Rimeika, M., Zalieckiene, E., Saulys, V., \& Zagorskis, A. (2012). Determination of organic matter by UV absorption in the ground water. Journal of Environmental Engineering and Landscape Management, 20(02), 163-7167. https://doi.org/10.3846/16486897.2012.674039

Albrektiene, R., Rimeika, M., \& Grazeniene, R. (2014, 22-23 May). Organic fractions and metal-organic complexes in the groundwater [CD]. In 9th International Conference "Environmental Engineering” (pp. 1-7). Vilnius, Lithuania.

Albrektiene, R., \& Rimeika, M. (2017, 27-28 May). Efficiency of removal of iron, manganese, ammonium and organic matter from groundwater [CD]. In 10th International Conference "Environmental Engineering" (pp. 1-7). Vilnius, Lithuania.

Ayoub, G. M., Zayyat, R. M., \& Al-Hindi, M. (2014a). Precipitation softening: a pretreatment process for seawater desalination. Environmental Science and Pollution Research, 21(4), 2876-2887. https://doi.org/10.1007/s11356-013-2237-1

Ayoub, G. M., BinAhmed, S. W., Al-Hindi, M., \& Azizi, F. (2014b). Coagulation of highly turbid suspensions using magnesium hydroxide: effects of slow mixing conditions. Environmental Science and Pollution Research, 21(17), 1050210513. https://doi.org/10.1007/s11356-014-2857-0

Brastad, K. S., \& He, Z. (2013). Water softening using microbial desalination cell technology. Desalination, 309, 32-37. https://doi.org/10.1016/j.desal.2012.09.015

Cheng, W., \& Ghi, F. (2002). A study of coagulation mechanisms of polyferric sulfate reacting with humic acid using a fluorescence-quenching method. Water Research, 36, 4583-4591. https://doi.org/10.1016/S0043-1354(02)00189-6

Chen, Y., Fan, R., An, D., Cheng, Y., \& Tan, H. (2016). Water softening by induced crystallization in fluidized bed. Journal of Environmental Sciences, 50, 109-116. https://doi.org/10.1016/j.jes.2016.08.014

Davis, C. C., \& Edwards, M. (2014). Coagulation with hydrolyz- ing metal salts: mechanisms and water quality impacts. Critical Reviews in Environmental Science and Technology, 44(4), 303-347. https://doi.org/10.1080/10643389.2012.718947

Duan, J. M., \& Gregory, J. (2003). Coagulation by hydrolysing metal salts. Advances Colloid Interface Science, 100, 475-502. https://doi.org/10.1016/S0001-8686(02)00067-2

Dowling, A., O'Dwyer, J., \& Adley, C. (2015). Lime in the limelight. Journal of Cleaner Production, 92, 13-22. https://doi.org/10.1016/j.jclepro.2014.12.047

Eikerokk, B. (2000). Removal of humic substances by coagulation. Chemical Water and Wastewater Treatment VI (pp. 173187). Berlin: Springer Verlag.

Esmaeilirad, N., Carlson, K., \& Ozbek, P. O. (2015). Influence of softening sequencing on electrocoagulation treatment of produced water. Journal of Hazardous Materials, 283, 721729. https://doi.org/10.1016/j.jhazmat.2014.10.046

Ghernaout, D. (2014). The hydrophilic/hydrophobic ratio vs. dissolved organics removal by coagulation: A review. Journal of King Saud University-Science, 26(3), 169-180.

https://doi.org/10.1016/j.jksus.2013.09.005

Ghernaout, D., \& Boucherit, A. (2015). Review of coagulation's rapid mixing for NOM removal. Journal of Research and Developments in Chemistry, 2015, 1-32. https://doi.org/10.5171/2015.926518

Ghernaout, D., Simoussa, A., Alghamdi, A., Ghernaout, B., Elboughdiri, N., Mahjoubi, A., Aichouni, M., \& El-Wakil, A. E. (2018). Combining lime softening with alum coagulation for hard Ghrib dam water conventional treatmen. International Journal of Advanced and Applied Sciences, 5(5), 61-70. https://doi.org/10.21833/ijaas.2018.05.008

Gao, Y., Yan, M. Q., \& Korshin, G. (2015). Effects of calcium on the chromophores of dissolved organic matter and their interactions with copper. Water Research, 81, 47-53. https://doi.org/10.1016/j.watres.2015.05.038

Gonczarow, T. O., Kołosow, I. W., \& Kapli, W. (2003). O formach nachorzdjenija metallow w poijerchnowstnych wodach. Gidrometeoizdat, 77, 73-89.

Huang, C., \& Shiu, H. (1996). Interactions between alum and organics in coagulation. Colloids and Surface, 113, 155-163. https://doi.org/10.1016/0927-7757(96)03543-1

Khatri, N., Tyagi, S., \& Rawtani, D. (2017). Recent strategies for the removal of iron from water: A review. Journal of Water Process Engineering, 19, 291-304. https://doi.org/10.1016/j.jwpe.2017.08.015

Knocke, R. W., Conley, L., \& Van Benschoten, J. E. (1992). Impact of dissolved organic carbon on the removal of iron during water treatment. Water Research, 26(11), 1515-1522. https://doi.org/10.1016/0043-1354(92)90072-C

Kowal, A. L., \& Świderska-Bróż, M. (2007). Oczyszczanie wody. Podstawy teoretyczne $i$ technologiczne, procesy $i$ urządzenia. PWN, Warszawa.

Krupińska, I. (2012). Suitability of coagulation for treatment of groundwater. Annual Set the Environmental Protection, 14, 491-501.

Krupińska, I., Kowalczyk, W., \& Szczepaniak G. (2013). Effect of coexistence ratio of organic substances and total iron in groundwater on its treatment efficacy. Ochrona Środowiska, 35(3), 27-34.

Krupińska, I. (2016). The impact of the oxidising agent type and coagulant type on the effectiveness of coagulation in the removal of pollutants from underground water with an increased content of organic substances. Journal of Environmental Engineering and Landscape Management, 24(01), 70-78. https://doi.org/10.3846/16486897.2015.1113179 
Krupińska, I. (2017a). Effect of organic substances on the efficiency of $\mathrm{Fe}(\mathrm{II})$ to $\mathrm{Fe}(\mathrm{III})$ oxidation and removal of iron compounds from groundwater in the sedimentation process. Civil and Environmental Engineering Reports, 26(3), 15-29. https://doi.org/10.1515/ceer-2017-0032

Krupińska, I. (2017b). The impact of potassium manganate (VII) on the effectiveness of coagulation in the removal of iron and manganese from groundwater with an increased content of organic substances. Civil and Environmental Engineering Reports, 27(4), 29-41. https://doi.org/10.1515/ceer-2017-0048

Liao, M. J., \& Randtke, S. (1985). Removing fulvic acid by lime softening. Journal American Water Works Association, 77(8), 78-88. https://doi.org/10.1002/j.1551-8833.1985.tb05592.x

Liao, M. J., \& Randtke, S. (1986). Predicting the removal of soluble organic contaminants by lime softening. Water Research, 20(1), 27-35.

https://doi.org/10.1016/0043-1354(86)90210-1

Lin, J., Couperthwaite, S. J., Huang, C., Dempsey, B., \& Hu, J. (2014). Fate of hydrolyzed Al species in humic acid coagulation. Water Research, 56(1), 314-324.

https://doi.org/10.1016/j.watres.2014.03.004

Lin, J., Couperthwaite, S. J., \& Millar, G. J. (2017). Applicability of iron based coagulants for pre-treatment of coal seam water. Journal of Environmental Chemical Engineering, 5(1), 11191132. https://doi.org/10.1016/j.jece.2017.01.041

Mahasti, N., Shih, H., Vu, V., \& Huang, Y. (2017). Removal of calcium hardness from solution by fluidized-bed homogeneous crystallization (FBHC) process. Journal of the Taiwan Institute of Chemical Engineers, 78, 378-385. https://doi.org/10.1016/j.jtice.2017.06.040

Marsidi, N., Hasan, H. A., \& Abdullah, S. R. S. (2018). A review of biological aerated filters for iron and manganese ions removal in water treatment. Journal of Water Process Engineering, 23, 1-12. https://doi.org/10.1016/j.jwpe.2018.01.010

Moel, P. J., Verberk, J. Q., \& Van Dijk, J. C. (2007). Drinking water: principles and practices. World Scientific Publishing.

Myszograj, S., Płuciennik-Koropczuk, E., Jakubaszek, A., \& Świętek, A. (2017). Cod fractions - methods of measurement and use in wastewater treatment technology. Civil and Environmental Engineering Reports, 24(1), 195-206.

https://doi.org/10.1515/ceer-2017-0014

Nowacka, A., Włodarczyk-Makuła, M., \& Macherzyński, B. (2014). Comparison of effectiveness of coagulation with aluminum sulfate and pre-hydrolyzed aluminum coagulants. Desalination and Water Treatment, 52, 3843-3851. https://doi.org/10.1080/19443994.2014.888129

Nowacka, A., \& Włodarczyk-Makuła, M. (2014). Impact of selected pre-hydrolyzed aluminum coagulants on improving of treated water quality. Annual Set the Environment Protection, 16, 336-350.

Płuciennik-Koropczuk, E., Jakubaszek, A., Świętek, A., Myszograj, S., \& Uszakiewicz, S. (2017). Cod fractions in mechanical-biological wastewater treatment plant. Civil and Environmental Engineering Reports, 24(1), 207-217. https://doi.org/10.1515/ceer-2017-0015

Pandey, A., Pandey, S., \& Mistra, V. (2000). Stability constants of metal-humic acid complexes and its role in environmental detoxification. Ecotoxicology and Environmental Safety, 47, 195-200. https://doi.org/10.1006/eesa.2000.1947

Randtke, S., Thiel, C. E., Marcia, Y., Liao, M. J., \& Yamaya, C. N. (1982). Removing soluble organic contaminants by limesoftening. Journal American Water Works Association, 74(4), 192-202. https://doi.org/10.1002/j.1551-8833.1982.tb04888.x
Regulation of the Minister of Health dated December 7, 2017 amending the regulation on the quality of drinking water mean for human consumption.

Rescorla, A., Semmens, M. J., \& Hozalski, R. M. (2017). Effect of NOM and Lime Softening on Geosmin Removal by PAC. Journal American Water Works Association, 109(4), 15-26. https://doi.org/10.5942/jawwa.2017.109.0030

Saxena, K., Brighu, U., \& Choudhary, A. (2018). Parameters affecting enhanced coagulation: a review. Environmental Technology Reviews, 7(1), 156-176. https://doi.org/10.1080/21622515.2018.1478456

Schnitzer, M., \& Skinner, S. I. M. (1996). Organo-metallic interactions in soils. Stability constants of $\mathrm{Cu}^{2+}, \mathrm{Fe}^{2+}$ and $\mathrm{Zn}^{2+}$ fullvic acids complexes. Soil Science, 102, 102-361.

Sharma, S. K. (2001). Adsorptive iron removal from groundwater. The Netherlands: Swets \& Zeitlinger B. V., Lisse.

Shiyan, L. N., Tropina, E. A., Machekhina, K. I., Gryaznova, E. N., \& An, V. (2014). Colloid stability of iron compounds in groundwater of Western Siberia. SpringerPlus, 3(1), 260-267. https://doi.org/10.1186/2193-1801-3-260

Sillanpää, M., Ncibi, M. C., Matilainen, A., \& Vepsäläinen, M. (2018). Removal of natural organic matter in drinking water treatment by coagulation: A comprehensive review. Chemosphere, 190, 54-71. https://doi.org/10.1016/j.chemosphere.2017.09.113

Świderska-Bróż, M. (1987). Sorption phenomena in natural waters and in water treatment processes. Ochrona Srodowiska, 2-3(32-33), 9-13.

Teh Fu Yen. (2007). Chemical processes for environmental engineering. London: Imperial College Press. https://doi.org/10.1142/p488

Urbanowska, A., \& Kabsch-Korbutowicz, M. (2016). Characteristics of natural organic matter removed from water along with its treatment. Environment Protection Engineering, 42, 183-195.

Wang, L. K., Wu, J. S., Shammas, N. K., \& Vaccari, D. A. (2005). Recarbonation and softening. Physicochemical Treatment Processes, 3, 199-228. https://doi.org/10.1385/1-59259-820-x:199

Wolska, M. (2011). Removal of total organic carbon fractions from surface water by coagulation. Ochrona Środowiska, 33(1), 9-12.

Wolska, M. (2013). Removal of precursors of chlorinated organic compounds in selected water treatment processes. Desalination and Water Treatment, 52(19-21), 3938-3946. https://doi.org/10.1080/19443994.2014.887502

Wolska, M. (2015). The effect of structure of organic matter in water on the adsorption efficiency. Przemyst Chemiczny, 94(6), 880-883.

Xu, Y., Chen, T., Liu, Z., Zhu, S., Cui, F., \& Shi, W. (2016). The impact of recycling alum-humic-floc (AHF) on the removal of natural organic materials (NOM): Behavior of coagulation and adsorption. Chemical Engineering Journal, 284, 10491057. https://doi.org/10.1016/j.cej.2015.09.069

Xu, H., Zhang, D., Xu, Z., Liu, Y., Jiao, R., \& Wang, D. (2018). Study on the effects of organic matter characteristics on the residual aluminum and flocs in coagulation processes. Journal of Environmental Sciences, 63, 307-317.

https://doi.org/10.1016/j.jes.2016.11.020

Yan, M. Q., Lu, Y. J., Gao, Y., Benedetti, M. F., \& Korshin, G. V. (2015). In-situ investigation of interactions between magnesium ion and natural organic matter. Environmental Science Technology, 49(14), 8323-8329.

https://doi.org/10.1021/acs.est.5b00003 
Zhou, Y., Yan, M., Liu, R., Wang, D., \& Qu, J. (2017). Investigating the effect of hardness cations on coagulation: The aspect of neutralisation through $\mathrm{Al}(\mathrm{III})$-dissolved organic matter (DOM) binding. Water Research, 115, 22-28. https://doi.org/10.1016/j.watres.2017.02.041

Zotter, K., \& Licsko, I. (1992). Coagulation and flocculation in alkaline media - the role of $\mathrm{Ca}^{2+}$ and $\mathrm{Mg}^{2+}$ ions. Chemical Water and Wastewater Treatment, II, 47-64.

https://doi.org/10.1007/978-3-642-77827-8_4 